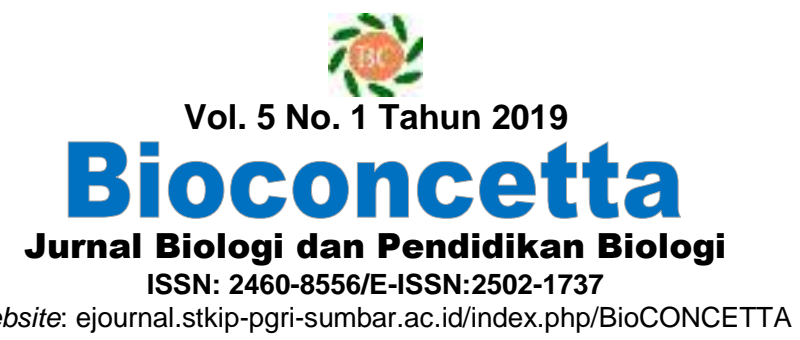

\title{
Tingkat Kehadiran dan Keanekaragaman Jenis Mammalia di Areal Reklamasi PT. Berau Coal, Kalimantan Timur
}

\author{
Hifzil Kirmi $^{1 *}$, Syaiful Anwar ${ }^{1}$, Muhammad Masyhuri ${ }^{1}$, Dandy E. Prasetiyo ${ }^{2}$ \\ ${ }^{1}$ Environmental Departement, PT. Berau Coal, Kab. Berau, Kalimantan Timur \\ ${ }^{2}$ Lembaga Peneltian dan Pengabdaian Masyarakat, Politeknik Sinar Mas Berau Coal \\ Email: hifzil.kirmi@beraucoal.co.id
}

\section{Info Artikel}

Sejarah Artikel

Diterima:

13 Juni 2019

Disetujui:

19 Juni 2019

Dipublikasikan:

31 Agustus 2019

Kata Kunci:

Revegetasi,

Mammalia

Keywords:

Revegetasi,

Mammals

\begin{abstract}
Abstrak
Penelitian ini bertujuan untuk melihat struktur komunitas Mammalia di areal reklamasi sebagai salah satu indikator keberhasilan program revegetasi yang dilakukan oleh PT. Berau Coal. Penelitian dilakukan di 3 areal reklamasi yaitu di wilayah Site Lati, Site Binungan dan Site Sambarata. Data yang digunakan adalah data pemantauan keanekaragaman hayati dari tahun 2014-2017. Beberapa analisis yang digunakan antara lain Indeks Keanekaragaman Hayati (H'), Indeks Kemerataan (E) dan Indeks Dominansi (D). Hasil penelitian menunjukan bahwa tingkat kehadiran Mammalia di areal reklamasi cukup tinggi yaitu dengan rata-rata per tahun kehadiran jenis sebanyak 21 jenis di Site Lati, 21 jenis di Site Binungan dan 23 Jenis di Site Sambarata. Sedangkan jika dilihat dari jumlah rata-rata tahunan individu yang hadir yaitu 70 individu di Site Lati, 56 Individu di Site Sambarata dan 74 Individu di Site Binungan. Tingkat kehadirian ini memberikan deksripsi bahwa areal reklamasi PT. Berau Coal telah mampu memberikan habitat yang baik bagi Mammalia. Sedangkan nilai keanekaragaman hayati (H') Mammalia yang di Lati 2,45; H' di Binungan 2,67 dan H' di sambarata 2,52.
\end{abstract}

\begin{abstract}
This research aims to see the diversity of mammals in reclamation area as one indicator of the success of revegetation program carried out by PT. Berau Coal. This research conducted in 3 reclamation areas, Lati Site, Binungan Site, and Sambarata Site. Data that used are biodiversity monitoring from 2014 - 2017. Some of analyzes used include Biodiversity Index $\left(H^{\prime}\right)$ and Equity Index $(E)$. The results showed that the presence of mammal in reclamation area was quite high with an average annual presence of 21 species in Lati Site, 21 species in Binungan Site, and 23 species in Sambarata Site. Whereas if viewed from the annual average number of individuals present were 70 individuals in Lati Site, 56 individuals in Sambarata Site, and 74 jndividuals im Binungan Site. This level of delivery provides a description that the reclamation area of PT. Berau Coal has able provide a good habitat for mammals. While the biodiversity values ( $H$ ') of mammals are at Lati 2.45; $H$ 'in Binungan 2.67 and $H^{\prime}$ in sambarata 2.52
\end{abstract}




\section{PENDAHULUAN}

Kegiatan penambangan batubara yang dilakukan dengan perencanaan, pelaksanaan, monitoring dan evaluasi yang baik akan memberikan kontribusi positif terhadap beberapa sektor seperti peningkatan ekonomi masyarakat, bangsa dan negara (Fatah, 2008; Balanay dkk., 2014), menciptakan lapangan pekerjaan (Fatah, 2008, Moritz dkk., 2017), dan investasi dari pihak asing (Fatah, 2008; Lokwood, 2016). Tetapi diketahui bersama, bahwa aktivitas manusia dalam pemanfaatan hutan secara berlebihan seringkali dapat mengakibatkan kerusakan hutan (Safitri dkk., 2016). Proses penambangan batubara juga sering kali memiliki dampak negatif baik bagi manusia maupun bagi lingkungan. Beberapa dampak negatif yang sering muncul antara lain perubahan kondisi lahan (Katoria dkk., 2013; Goswami, 2015; Hidayat dkk., 2015) pencemaran lingkungan (tanah, air dan udara) dan kerusakan keanekaragaman hayati (Ardhana, 2010; Katoria dkk., 2013; Goswami, 2015).

Pemerintah mengeluarkan PP No 78 tahun 2010 tentang reklamasi dan pascatambang sebagai upaya untuk mengurangi dampak kerusakan keanekaragaman hayati yang diakibatkan oleh adanya aktivitas penambangan. Disebutkan dalam pasal 2 ayat (1) Pemegang IUP (Izin Usaha Pertambangan) Eksplorasi dan IUPK (Izin Usaha Pertambangan Khusus) Eksplorasi wajib melaksanakan reklamasi dan ayat (2) Pemegang IUP Operasi Produksi dan IUPK Operasi Produksi wajib melaksanakan reklamasi dan pasca tambang. Reklamasi merupakan proses perbaikan lingkungan akibat adanya efek negatif dari suatu kegiatan (Sloss, 2013) dalam hal ini adalah kegiatan penambangan batubara sehingga kondisi lahan pasca tambang menjadi aman, stabil dan tidak mudah tererosi serta dapat dimanfaatkan kembali (Darwo, 2007).

Kegiatan reklamasi diharapkan mampu mengembalikan kondisi lahan pascatambang mendekati dan atau sama dengan rona awal lingkungn. Kegiatan ini menjadi proses penting untuk menyediakan kembali habitat bagi flora dan fauna dilokasi pascatambang. Kehadiran flora-fauna alami merupakan bio-indikator penting bagi proses dan tahapan-tahapan yang sangat menentukan bagi keterpulihan bentang lahan revegetasi pasca tambang secara ekologis (Sudarmadji dan Hartati, 2013; Buchori dkk., 2010).

Satwa liar memiliki peran dalam menjaga keseimbangan proses ekosistem di alam. Peran setiap organisme dalam ekosistem sangat bervariasi yang dipengaruhi oleh adanya proses, sifat dan besarnya individu dari suatu organisme (Naeem dkk., 1999). Secara umum, beberapa jenis satwaliar merupakan konsumen pertama dalam piramida makanan, sedangkan beberapa jenis lainnya merupakan konsumen kedua, ketiga dan seterusnya. Dengan demikian, kelangsungan kehidupan satwa akan tergantung satu sama lain; dan penurunan populasi salah satu diantaranya akan berdampak negatif terhadap kesinambungan jaring-jaring makanan dan menghambat kelancaran arus dan siklus energi (Majelis Ulama Indonesia, 2017).

Salah satu satwa liar yang memiliki peranan dalam ekosistem yaitu Mammalia. Mammalia 
memegang peranan penting dikehidupan liar sebagai salah satu penyeimbang dalam ekosistem. Mammalia menempati berbagai trophic level dalam rantai makanan mulai dari Mammalia herbivora sebagai predator tumbuhan pada urutan terbawah hingga Mammalia karnivora sebagai pemangsa urutan teratas (top predator) (Roemer dkk., 2009). Mammalia juga dapat berperan untuk membantu menyuburkan tanah, menyebarkan biji, penyerbukan bunga, dan pengendali hama/ penyakit. Selain itu, Mammalia juga memiliki nilai penting secara ekonomi dan estetika. Dari segi kelimpahan Mammalia biasanya lebih kecil dibandingkan dengan jenis lainnya, tetapi Mammalia sering disebut sebagai "Ecological Landscaper" (Sinclair, 2003) karena kemampuan Mammalia dalam mengubah kondisi fisik dan biologi suatu landscape sehingga berpengaruh terhadap kondisi ekosistem (Hurlbert 1997, Paine 2000 dalam Sinclair, 2003).

Keberadaan Mammalia dalam suatu komunitas banyak dipengaruhi oleh lingkungan tempat hidup mereka. Mammalia terrestrial termasuk ke dalam jenis organisme homeotermal yang sering melakukan pemilihan lingkungan hidup secara musiman (Boyce 1979 dalam Kartono dkk., 2016). Hal ini disebabkan kemampuannya untuk menyesuaikan diri dengan lingkungan sekitar (Zug, 1993). Curah hujan maksimum dan tahunan merupakan peubah kondisi habitat penting yang dapat menjelaskan distribusi Mammalia (Newbold dkk., 2009 dalam Kartono dkk., 2016).

Penelitian ini bertujuan untuk melihat tingkat kehadiran dan keanekaragaman jenis Mammalia selama kurun waktu 8 tahun (20142017) di areal reklamasi sebagai pendukung keberhasilan kegiatan reklamasi dan revegetasi PT. Berau Coal, Kalimantan Timur.

\section{BAHAN DAN METODE}

Penelitian dilaksanakan pada 3 areal konsesi penambangan batubara PT. Berau Coal yaitu Site Lati, Site Binungan dan Site Sambarata. Pada ketiga lokasi tersebut PT. Berau Coal melalui Dept. Environmental melakukan kegiatan reklamasi dan revegetasi serta melakukan pemantauan kondisi hutan setiap tahun. Data penelitian diambil dari kegiatan pemantauanya tahun 2014- 2017.

Survei dilakukan untuk mengidentifikasi ada tidaknya jenis Mammalia di masing-masing lokasi. Metode yang digunakan untuk mengumpulkan data dengan beberapa cara;

Observasi (recce walk). Metode ini dilakukan dengan berjalan mengikuti jalur yang sudah ada, baik jalur rintisan maupun jalur satwa. Data yang dikumpulkan meliputi semua bentuk perjumpaan dengan satwa Mammalia baik secara langsung maupun tidak seperti jejak kaki, bekas cakaran, kotoran dan suara. Pengamatan dilakukan mengikuti waktu aktif Mammalia pada pagi hari pukul 07.00-10.00 WITA, sore hari pukul 16.00-18.00 WITA, dan malam hari pukul 19.00-20.00 WITA. Metode ini efektif untuk pengumpulan data berbagai jenis Mammalia baik yang aktif pada waktu senja (crepuscular), siang (diurnal), dan malam (nocturnal) (Atmoko, 2017).

Life Trap. Penggunaan metode perangkap ini ditujukan untuk menangkap satwa-satwa Mammalia 
kecil khususnya jenis hewan pengerat (Rodentia). Umpan yang digunakan adalah kelapa dan ikan asin. Jumlah perangkap yang digunakan berjumlah lima buah yang dipasang secara sengaja (purposive) di beberapa titik dengan kemungkinan potensi perjumpaan tinggi dan diperiksa setiap 1x24 jam. Satwa yang tertangkap kemudian dimasukkan kedalam kantung kain untuk kemudian diidentifikasi di camp.

Camera Trap. Penggunaan perangkap kamera (camera trap) dimaksudkan untuk mendapatkan gambar ataupun video satwa Mammalia yang sensitif dan susah untuk dijumpai secara langsung. Kamera dipasang pada beberapa titik yang berpotensi besar dilalui satwa Mammalia, baik di jalur pengamatan ataupun disekitar sungai. Perangkap kamera yang digunakan adalah merek Bushnell yang dilengkapi sensor gerak dan panas sebanyak enam unit (Imanuddin, et al., 2011; Septian dan Sidabutar, 2015).

Wawancara. Pengambilan data dengan cara mewawancarai masyarakat sekitar atau petugas lapangan mengenai keberadaan jenis Mammalia yang terdapat di lokasi pengamatan. Keterangan dari masyarakat atau petugas tersebut dapat diverifikasi dengan mencocokan dengan buku panduan (field guide) Mammalia (Japan International Cooperation Agency, 2002; Septian dan Sidabutar, 2015).

Untuk menganlisis data tingkat kehadirian Mammalia pada areal reklamasi dianalisis secara deskriptif yaitu dengan melihat jumlah kehadiran Mammalia pada setiap tahun pengamatan. Selain itu analisis juga dilakukan untuk melihat tingkat keragaman Mammalia.

Beberapa indeks yang digunakan untuk melihat tingkat keragaman Mammalia antara lain: Indeks Keanekaragaman Spesies. Analisis indeks keanekaragaman spesies dilakukan dengan menggunakan persamaan Shannon-Wiener sebagai berikut:

$$
\begin{gathered}
H^{\prime}=-\sum_{P i=\frac{n i}{N}} P i \ln P i
\end{gathered}
$$

Dimana H merupakan Indeks Keanekaragaman Shanon Wiener, $\mathrm{Ni}$ adalah jumlah Individu Spesiesi, dan $\mathrm{N}$ adalah jumlah Total Individu

Indeks Kemerataan Jenis. Dalam studi ini indeks kemerataan spesies dihitung berdasarkan persamaan Shannon-Wiener sebagai berikut:

$$
E_{1}=\frac{H^{\prime}}{H \max }=\frac{H^{\prime}}{\operatorname{Ln} S}
$$

Dimana Ni adalah jumlah Individu tiap spesies, dan $\mathrm{N}$ adalah jumlah Individu seluruh spesies

\section{HASIL DAN PEMBAHASAN}

Areal reklamasi PT. Berau Coal menjadi salah satu habitat bagi satwa liar dari jenis Mammalia. Keberadaan Mammalia di areal reklamasi dibuktikan dengan adanya hasil obeservasi yang dilakukan oleh tim dari Dept. Envi. Berikut ini merupakan data jumlah famili, jumlah jenis dan jumlah individu Mammalia yang ada di areal revegetasi. 
Tabel 1. Jumlah Jenis Mammalia yang Ditemukan Areal Reklamasi PT. Berau Coal.

\begin{tabular}{lccc}
\hline \multirow{2}{*}{ Parameter } & \multicolumn{3}{c}{ Tahun } \\
\cline { 2 - 4 } & Lati & Binungan & Sambarata \\
\hline Jumlah Individu & 70 & 56 & 74 \\
Jumlah Jenis & 21 & 21 & 23 \\
Jumlah Famili & 13 & 11 & 11 \\
\hline
\end{tabular}

Mammalia yang ditemukan selama proses pengamatan pada tahun 2014 hingga tahun 2017 diperoleh jumlah yang beragam baik ditingkatan individu, jenis maupun famili. Jumlah individu rata-rata pertahun paling tinggi ditemukan yaitu di areal reklamasi Sambarata sebanyak 74 individu sedangkan untuk areal reklamasi Lati sebanyak 70 individu dan Binungan sebanyak 56 individu.
Dari rata-rata jumlah jenis, dua lokasi yaitu Lati dan Binungan memiliki jumlah jenis yang sama sebanyak 21 jenis. Sedangkan untuk Sambarata memiliki rata-rata jumlah jenis tertinggi yaitu 23 jenis. Adapun untuk rata-rata jumlah family lokasi Binungan dan Sambarata memiliki jumlah famili 11, dan untuk Lati memiliki jumlah famili sebanyak 13 . Keragaman Mammalia

Tabel 2. Komposisi Jenis Mammalia yang Ditemukan Selama Kegiatan Pemantauan Di Areal Reklamasi PT. Berau Coal.

\begin{tabular}{|c|c|c|c|c|c|}
\hline Famili & Nama Ilmiah & $\begin{array}{c}\text { Nama } \\
\text { Lokal/Indonesia }\end{array}$ & $\begin{array}{c}\begin{array}{c}\text { Areal } \\
\text { reklamasi }\end{array} \\
\mathrm{LT}\end{array}$ & $\begin{array}{c}\begin{array}{c}\text { Areal } \\
\text { reklamasi }\end{array} \\
\mathrm{LT}\end{array}$ & $\begin{array}{c}\begin{array}{c}\text { Areal } \\
\text { reklamasi }\end{array} \\
\text { LT }\end{array}$ \\
\hline Cercopithecidae & Macaca fascicularis & $\begin{array}{l}\text { Monyet ekor } \\
\text { panjang }\end{array}$ & + & + & - \\
\hline Cercopithecidae & Macaca nemestrina & Monyet beruk & + & + & + \\
\hline Cercopithecidae & Presbytis hosei & Lutung banggat & - & - & + \\
\hline Cercopithecidae & Presbytis rubicund & Lutung merah & + & + & + \\
\hline Cercopithecidae & Trachypithecus cristatus & Lutung kelabu & - & + & + \\
\hline Cervidae & Cervus unicolor & $\begin{array}{l}\text { Rusa Sambar/ } \\
\text { Payau }\end{array}$ & + & + & + \\
\hline Cervidae & Muntiacus atherodes & Kijang kuning & + & - & + \\
\hline Cervidae & Muntiacus muntjak & Kijang & + & + & + \\
\hline Cynocephalidae & Galeopterus variegates & Kubung & + & + & - \\
\hline Erinaceidae & Echinosorex gymnurus & Rindil Bulan & - & + & - \\
\hline Felidae & Prionailurus bengalensis & Kucing hutan & + & + & - \\
\hline Hylobatidae & Hylobates muelleri & Owak alawat & + & + & + \\
\hline Hylobatidae & Helarctos malayanus & & - & + & + \\
\hline Hystricidae & Hystrix brachyura & Landak raya & + & + & + \\
\hline Hystricidae & Hystrix crassispinis & Landak butun & + & + & - \\
\hline Hystricidae & Trichys fasciculata & $\begin{array}{l}\text { Angkis ekor } \\
\text { panjang }\end{array}$ & + & - & - \\
\hline Lorisidae & Nycticebus menagensis & Kukang & + & + & + \\
\hline Manidae & Manis javanica & Trenggiling & + & + & - \\
\hline Megadermatidae & Megaderma spasma & $\begin{array}{l}\text { Kelelawar } \\
\text { Vampir Palsu }\end{array}$ & + & - & - \\
\hline Muridae & Chiropodamis gliroides & Tikus kecil & + & - & - \\
\hline Muridae & Leopoldamy ssabanus & $\begin{array}{l}\text { Tikus raksasa } \\
\text { ekor panjang }\end{array}$ & + & - & - \\
\hline Muridae & Maxomys baeodon & Tikus-duri Kecil & + & - & - \\
\hline Muridae & Maxomys surifer & $\begin{array}{l}\text { Tikus duri } \\
\text { merah }\end{array}$ & + & - & + \\
\hline Muridae & Maxomys whiteheadi & $\begin{array}{l}\text { Tikus duri ekor } \\
\text { pendek }\end{array}$ & + & + & + \\
\hline Muridae & Nivivente rcremoniventer & $\begin{array}{l}\text { Tikus-pohon } \\
\text { ekor-polos }\end{array}$ & + & + & - \\
\hline
\end{tabular}




\begin{tabular}{|c|c|c|c|c|c|}
\hline Famili & Nama Ilmiah & $\begin{array}{c}\text { Nama } \\
\text { Lokal/Indonesia }\end{array}$ & $\begin{array}{c}\begin{array}{c}\text { Areal } \\
\text { reklamasi }\end{array} \\
\text { LT }\end{array}$ & $\begin{array}{c}\begin{array}{c}\text { Areal } \\
\text { reklamasi }\end{array} \\
\text { LT }\end{array}$ & $\begin{array}{c}\begin{array}{c}\text { Areal } \\
\text { reklamasi }\end{array} \\
\text { LT }\end{array}$ \\
\hline Muridae & Rattus exulans & Tikus Ladang & + & - & - \\
\hline Muridae & Rattus tiomanicus & Tikus belukar & + & + & + \\
\hline Muridae & $\begin{array}{l}\text { Rattus } \\
\text { tiomanicusjalorensis }\end{array}$ & Tikus Belukar & + & - & - \\
\hline Muridae & Rattus tiomanicussabae & Tikus Belukar & + & - & + \\
\hline Mustelidae & Lutra perspicillata & $\begin{array}{l}\text { Berang-oerang } \\
\text { wregul }\end{array}$ & - & + & - \\
\hline Nycteridae & Nycteris tragata & Pedan sunda & - & - & + \\
\hline Pteropodidae & Balionycteris maculata & $\begin{array}{l}\text { Codot Sayap- } \\
\text { totol }\end{array}$ & - & + & - \\
\hline Pteropodidae & Chironax melanocephalus & $\begin{array}{l}\text { Codot kepala- } \\
\text { hitam }\end{array}$ & + & - & - \\
\hline Pteropodidae & Cynopterus brachyotis & Codo tkrawar & + & + & + \\
\hline Pteropodidae & Cynopterus horsfieldi & Codot horsfield & - & + & + \\
\hline Pteropodidae & Cynopterus minitus & Codot mini & + & + & + \\
\hline Pteropodidae & Eonycteris spelaea & kecil & - & + & - \\
\hline Pteropodidae & Hemigalus derbyanus & Musang Belang & - & - & + \\
\hline Pteropodidae & Macroglossus minimus & $\begin{array}{l}\text { Codot-pisang } \\
\text { coklat }\end{array}$ & + & + & + \\
\hline Pteropodidae & Macroglossus sobrinus & $\begin{array}{l}\text { Codot-Pisang } \\
\text { besar }\end{array}$ & - & - & + \\
\hline Pteropodidae & Megaerops ecaudatus & Tungkol biasa & - & - & + \\
\hline Pteropodidae & Penthetor lucasii & $\begin{array}{l}\text { Codot Kecil- } \\
\text { kelabu }\end{array}$ & + & - & + \\
\hline Pteropodidae & $\begin{array}{l}\text { Rousettus } \\
\text { amplexicaudatus }\end{array}$ & Nyapbiasa & + & - & + \\
\hline Rhinolophidae & Rhinolophus creaghi & ladam creagh & - & - & + \\
\hline Rhinolopidae & Rhinolophus affinis & Prok-bruk hutan & - & + & - \\
\hline Sciuridae & Callosciurus baluensis & Bajing Kinabalu & + & + & + \\
\hline Sciuridae & Callosciurus notatus & Bajing kelapa & + & + & + \\
\hline Sciuridae & Callosciurus orestes & Bajing kelabu & - & + & + \\
\hline Sciuridae & Callosciurus prevostii & $\begin{array}{l}\text { Bajingtigawarna } \\
\text { Bajing- }\end{array}$ & + & + & + \\
\hline Sciuridae & Exilisciurus exilis & $\begin{array}{l}\text { kerdildataran- } \\
\text { rendah }\end{array}$ & + & + & + \\
\hline Sciuridae & Hylopetes spadiceus & $\begin{array}{l}\text { Bajing-terbang } \\
\text { pipi-merah }\end{array}$ & + & - & + \\
\hline Sciuridae & Lariscus insignis & $\begin{array}{l}\text { Bajing tanah } \\
\text { bergaris tiga }\end{array}$ & - & + & - \\
\hline Sciuridae & Nannosciurus melanotis & $\begin{array}{l}\text { Bajing kerdil } \\
\text { telinga hitam }\end{array}$ & - & + & - \\
\hline Sciuridae & Petaurista $s p$ & Bajing terbang & + & - & - \\
\hline Sciuridae & Ratufa affinis & $\begin{array}{l}\text { Jelarang } \\
\text { bilalang }\end{array}$ & + & + & + \\
\hline Sciuridae & Rhinosciurus laticaudatus & $\begin{array}{l}\text { Bajing tanah } \\
\text { moncong } \\
\text { runcing }\end{array}$ & - & + & - \\
\hline Sciuridae & Sundasciurus hippurus & $\begin{array}{l}\text { Bajing ekor- } \\
\text { kuda }\end{array}$ & - & - & + \\
\hline Sciuridae & Sundasciurus lowi & $\begin{array}{l}\text { Bajing ekor } \\
\text { pendek }\end{array}$ & - & - & + \\
\hline Sciuridae & Sundasciurus tenuis & Bajing bancirot & + & + & + \\
\hline Sciuridae & Sundasciurus tenuis & Bajing bancirot & - & - & - \\
\hline Suidae & Sus barbatus & Babi berjenggot & + & + & + \\
\hline Tarsiidae & Cephalopachus bancanus & Krabuku ingkat & - & - & + \\
\hline Tragulidae & Tragulus javanicus & Pelanduk kancil & + & - & + \\
\hline Tragulidae & Tragulus kanchil & Pelanduk Kancil & + & + & + \\
\hline Tupaiidae & Dendrogale melanura & Tupai ekor-kecil & + & + & - \\
\hline Tupaiidae & Tupai spp & Tupai & + & - & - \\
\hline Tupaiidae & Tupaia gracilis & Tupai ramping & + & + & + \\
\hline Tupaiidae & Tupaia minor & Tupai kecil & + & + & + \\
\hline
\end{tabular}




\begin{tabular}{|c|c|c|c|c|c|}
\hline \multirow[t]{2}{*}{ Famili } & \multirow[t]{2}{*}{ Nama Ilmiah } & \multirow{2}{*}{$\begin{array}{c}\text { Nama } \\
\text { Lokal/Indonesia }\end{array}$} & $\begin{array}{c}\text { Areal } \\
\text { reklamasi }\end{array}$ & $\begin{array}{c}\text { Areal } \\
\text { reklamasi }\end{array}$ & $\begin{array}{c}\text { Areal } \\
\text { reklamasi }\end{array}$ \\
\hline & & & LT & LT & LT \\
\hline Tupaiidae & Tupaia picta & Tupai tercat & + & + & + \\
\hline Tupaiidae & Tupaia tana & Tupaitanah & + & + & + \\
\hline Ursidae & Helarctos malayanus & Beruang madu & + & - & + \\
\hline Vespertilionidae & Kerivoula intermedia & Lenawai Sabah & - & - & + \\
\hline Viverridae & Arctictis binturong & Binturung & + & - & + \\
\hline Viverridae & Arctogalidia trivirgata & Musang akar & + & + & + \\
\hline Viverridae & Diplogale derbyanus & Musang belang & - & - & + \\
\hline Viverridae & Herpestes brachyurus & $\begin{array}{l}\text { Garangan ekor } \\
\text { pendek }\end{array}$ & + & - & - \\
\hline Viverridae & Paguma larvata & Musang galing & - & + & + \\
\hline Viverridae & $\begin{array}{l}\text { Paradoxurus } \\
\text { hermaphroditus }\end{array}$ & Musang luwak & + & + & - \\
\hline Viverridae & Viverra tangalunga & $\begin{array}{l}\text { Tenggalung } \\
\text { malaya }\end{array}$ & + & + & + \\
\hline
\end{tabular}

Hasil perhitungan terhadap indeks keragaman menunjukan bahwa nilai Indeks Keanekaragaman (H') dan
Indeks kemerataan pada tiga lokasi pengamatan yaitu sebagai berikut:

Tabel 3. Nilai Parameter Indeks Pada Jenis Mammalia yang Ditemukan Di Areal Reklamasi PT. Berau Coal.

\begin{tabular}{lccc}
\hline \multirow{2}{*}{ Parameter } & \multicolumn{3}{c}{ Areal Reklamasi } \\
\cline { 2 - 4 } & LT & BN & SM \\
\hline Indeks Keanekaragaman (H') & 2,45 & 2,67 & 2,52 \\
Indeks Kemerataan (E) & 0,80 & 0,88 & 0,80 \\
\hline Keterangan : LT = Lati, BN = Binungan, SM = Sambarata & &
\end{tabular}

Secara keseluruhan nilai keanekaragaman jenis Mammalia yang ditemukan hamper merata disemua lokasi observasi yaitu dalam kategori sedang dengan nilai H' 2,45 di Lati, 2,67 di Binungan dan 2,52 di Sambarata.

Berdasarkan hasil penelitian jumlah jenis Mammalia memiliki kesamaan jumlah jenis dengan hasil penelitian yang dilakukan oleh Maharadatunkamsi dkk., 2015 dilokasi Cagar Alam Leuweung, Kab. Garut yaitu sebanyak 21 jenis. Tetapi jumlah Mammalia di areal reklamasi PT. Berau Coalmasih lebih tinggi jika dibandingkan dengan hasil pemantauan di kawasan industri semen PT Indocement yaitu ditemukan sebanyak 17 jenis Mammalia (Kartono, 2016) dan lebih rendah jika dibandingkan dengan hasil penelitian di Taman Nasional Sebagau, Kalimantan Tengah yaitu sebanyak 46 jenis (Mustari dkk., 2010).

Beberapa jenis Mammalia yang hadir pada ketiga areal reklamasi antara lain Macaca nemestrina, Tupaia minor, Callosciurus notatus, Callosciurus prevostii, Exilisciurus exilis, Ratufa affinis, Cervus unicolor, Tragulus napu, Sus barbatus, Hylobates muelleri, Arctogalidia trivirgata dan Cynopterus bracyotis. Tingkat kehadiran Mammalia ini juga cukup menarik, karena setiap areal reklamasi memiliki karakter kehadiran Mammalia yang berbeda. Pada areal reklamasi Site Lati, jenis yang sering muncul setiap tahun-nya adalah Rusa Sambar (Cervus unicolor), Pelanduk Kancil (Tragulus kanchil) dan 
Pelanduk Nupu (Tragulus napu). Berbeda dengan lokasi Sambarata, jenis yang sering muncul adalah monyet ekor panjang (Macaca fascicularis) dan monyet berau (Macaca nemestrina). Sedangkan di Binungan jenis kehadiran Mammalia cenderung lebih merata.

Dari banyaknya jumlah Mammalia yang ditemukan di areal reklamasi, ada beberapa jenis yang sering hadir selama periode pengamatan. Babi berjenggot (Sus barbatus) menjadi satu jenis Mammalia yang selalu muncul setiap tahun disemua lokasi pengamatan areal reklamasi. Babi merupakan jenis Mammalia pemakan segala (omnivora) sehingga jenis ini lebih mudah beradaptasi dengan kondisi di kawasan revegetasi karena cukup beragamnya jenis makanan. Dari pengamatan lapangan jenis ini akan semakin banyak apabila di dalam kawasan revegetasi ditanami pohon buah. Selain itu, babi mempunyai toleransi yang tinggi terhadap kondisi iklim yang beragam (Ardana dan Putra, 2008).

Jenis primata yang banyak ditemukan di dalam kawasan revegetasi adalah monyet ekor panjang (Macaca fascicularis), jenis ini ditemukan dalam kelompok-kelompok sedang mencari makanan di pohonpohon buah yang ditanam di dalam lahan revegetasi. Sesuai dengan namanya, primate ini memiliki ekor yang panjang, lebih panjang dari ukuran panjang kepala dan badannya. Jenis monyet ini adalah primata yang paling adaptif dimuka bumi setelah manusia. Primata ini tersebar luas diberbagai jenis pulau di Indonesia seperti di Sumatera, Kalimantan, Jawa dan pulau-pulau kecil lainnya di Indonesia (Fooden, 1995). Habitatnya mulai dari di daerah pesisir yaitu hutan mangrove dan hutan pantai, hutan di sepanjang sungai-sungai besar, sampai di daerah dataran tinggi. Selain itu juga dijumpai disekitar kebun dan permukiman masyarakat. Kehadiran jenis Mammalia ini dalam kawasan revegetasi diduga karena di dalam kawasan revegtasi terdapat sumber makanan baru yaitu jenis buah-buahan, biji dan dedaunan.

Perbedaan jenis satwa liar yang hadir pada tiap lokasi dapat disebabkan karena adanya perbedaan kondisi landscape (fragmentasi habitat) (Campos dkk., 2013), tegakan vegetasi (struktur hutan), jenis ketersediaan makanan dan juga kondisi iklim (Kartono, 2016). Fenomena ini sangat menarik untuk dapat dilakukan penelitian dan pemantauan lebih lanjut sehingga dapat diketahu faktor utama yang menyebabkan adanya perbedaan tersebut. Ada beberapa penyebab sehingga terjadi beberapa perbedaan hasil pengamatan1) kondisi cuaca dan waktu pengamatan yang tidak sesuai dimungkinkan sebab dari beberapa Mammalia yang tidak terdeteksi (Kartono, 2016); 2) Usaha yang dilakukan tim pengamatan kurang banyak memiliki waktu; 3) Bisa juga karena mulai tingginya tingkat perburuan yang dilakukan oleh masyarakat. 
Penilaian keragaman Mammalia di areal reklamasi dilakukan dengan melakukan analisis beberapa indeks diantaranya adalah indeks keanekaragaman spesies, indeks kemerataan spesies dan indeks dominansi spesies. Keanekaragaman spesies merupakan suatu karakteristik tingkatan komunitas berdasarkan organisasi biologinya yang dapat digunakan untuk menyatakan struktur komunitas (Soegianto, 1994 dalam Mustari dkk., 2010).

Berdasarkan secara keseluruhan nilai keanekaragaman jenis Mammalia yang ditemukan hampir merata disemua lokasi observasi yaitu dalam kategori sedang dengan nilai $\mathrm{H}^{\prime} 2,45$ di Lati, 2,67 di Binungan dan 2,52 di Sambarata. Nilai kategori sedang artinya bahwa kondisi spesies Mammalia di areal reklamasi memiliki produktivitas cukup, kondisi ekosistem cukup seimbang dan tekanan ekologis sedang (Barbour dkk., 1987).

\section{SIMPULAN}

Keberadaan areal reklamasi dari keberhasilan proses revegetasi memberikan pengaruh yang baik terhadap keterpulihan kondisi lingkungan dan keanekaragaman hayati. Kehadiran Mammalia di areal reklamasi memberikan gambaran bahwa areal reklamasi menuju kondisi ekosistem yang lebih stabil. Kehadiran Mammalia khususnya Mammalia besar dapat mengindikasikan tiga hal; satwa tersebut masuk ke areal revegetasi hanya untuk melintas saja, satwa liar mencari sumber pakan, dan satwa liar mencari tempat perlindungan dan habitat baru.

\section{DAFTAR PUSTAKA}

Ardhana, IPG. 2010. Konservasi Keanekaragaman Hayati pada Kegiatan Pertambangan di Kawasan Hutan di Indonesia. Jurnal Ilmu Pertanian Indonesia. 15 (2): $71-77$.

Atmoko, SSU., Saputra, F., Suwarso., Husein, H.Z., Triandika, K., dan Fahrizal, D. 2017. Keanekaragaman Hayati Blok Sembakung kabupaten Nunukan Kalimantan Utara. NSp UNAS. Jakarta.

Balanay, RM., Yorobe, JM., Reyes, SG., Castanos AMJ., Maglentes, OK., Pandoyos, JB., and Charry, CC. 2014. Analyzing the Income Effects of Mining with Instrumental Variables for Poverty Reduction Implications in Caraga Region, Philippines. Journal of International and Global Economic Studies Vol. 7(1): 20-31.

Buchori, D., Rizal, A., Rahayu, AG., dan Masnur, R. 2018. Insect diversity in post-mining areas: Investigating their potential role as bioindicator of reclamation success. Biodiversitas Vol 19 (5): 1696-1702.

Campos, PRA., Rosas, A., de Oliveira, VM., and Gomes, MAF. 2013. Effect of Landscape Structure on Species Diversity. PLoS One. Vol. 8(6): e66495

Fatah, L. 2008. The Impact of Coal Mining on the Economy and Environment of South Kalimantan Province, Indonesia. 
Asean Economic Bulletin. 25(1):85-98.

Fooden J. 1995. Systematic review of Southeast Asian long tail macaques, Macacafascicularis. Zoology. (81): 1- 206.

Goswami, S. 2015. Impact of Coal Mining on Environment. European Researcher. 92 (3): $185-196$.

Hidayat, W., Rustiadi, E., dan Kartodihardjo, H. 2015. Dampak Pertambangan Terhadap Perubahan Penggunaan Lahan dan Kesesuaian Peruntukan Ruang (Studi Kasus Kabupaten Luwu Timur, Provinsi Sulawesi Selatan). Jurnal Perencanaan Wilayah dan Kota. 26 (2): 130146.

Imanuddin, Persey, S., Priatna D., Laura D'Arcy, L., dan Sadikin, L. 2011. Practical Toolkit For Identifying and Monitoring Biodiversity in Oil Palm Lanscapes. The Zological Society of London. Bogor.

Japan International Cooperation Agency. 2002. Technical Manual Series on the Feasibility Study on the Forest Management Plan in the Central Highland in Socialist Republic of Viet Nam. Japan Overseas Forestry Consultants Association (JOFCA). Pasco Corporation, Viet Nam.

Kartono, AP., Choirunnisa, A., Prayogi, KD., dan Chandra, R. 2016. Variabilitas Musiman Jenis Mammalia di Kawasan Industri Semen PT Indocement Tunggal Prakarsa TBK Unit Palimanan, Jawa Barat. Jurnal Biologi Indonesia. 12(2): 195202.
Katoria, D., Sehgal, D., dan Kumar, S. 2013. Environment Impact Assessment of Coal Mining. International Journal of Environmental Engineering and Management. 4 (3): 245-250.

Lockwood, K. 2016. Analysis of Investment in Mining. TIPS Annual Forum 1 - 33 .

Maharadatunkamsi, T., Prakarsa, B. T., Kurnianingsih. 2015. Struktur Komunitas Mamalia di Cagar Alam Leuweung Sancang, Kabupaten Garut, Jawa Barat. Zoo Indonesia. 24 (1): 51-59

Majelis Ulama Indonesia. 2017. Pelestarian Satwa Langka untuk Keseimbangan Ekosistem: Penuntun Sosialisasi Fatwa MUI No 4, 2014, tentang Fatwa Pelestarian Satwa Langka untuk Menjaga Keseimbangan Eksosistem. Jakarta.

Moritz, T., Ejdemo, T., Söderholm, P., and Warell, L. 2017. The Local Employment Impacts of Mining: an Econometric Analysis of Job Multipliers in Northern Sweden. Miner Econ. 30 :53-65.

Mustari, A. B., Surono, H., Fatimah, D. N., Setiawan, A., dan Febria, R. 2010. Keanekaragaman Jenis Mammalia di Taman Nasional Sebangau, Kalimantan Tengah. Media Konservasi. 15 (3): 115 119.

Naeem, S., Chapin, C. F. S., Costanza, R., Ehrlich, P. R., Golley, F. B., Hooper, D. U., Lawton, J. H., Neill, R. V. O., Mooney, H. A., Sala, O. E., Symstad, A. J., dan Tilman D. Tilman Biodiversity and Ecosystem Functioning: Maintaining Natural Life 
Support Processes. Issues in Ecology Vol. 4.

Roemer, GW., Gompper, ME., dan Valkenburgh, BV. 2009. The Ecological Role of the Mammalian Mesocarnivore. BioScience. 59 (2): 165-173.

Safitri, E., Rizki, dan Sari, WL. 2016. Inventarisasi Pohon di Hutan Pinang Makmur Kecamatan Timpeh Kabupaten Dharmasraya. Jurnal Bioconcetta. II (1): $75-80$.

Septiani, Y., dan Sidabutar, H. 2015. Biodiversity Survey In the Sub
Waershed Embaloh, Betung Kerihun National Park. ITTO PD 617/11. Jakarta.

Sinclair, ARE. 2003. The Role of mammals as Ecosystem Landscapers. Alces Vol. 39: 161176.

Sudarmadji, T., dan Hartati, W. 2013. Upaya Pemulihan dan Potensi Keterpulihan Lahan Pasca Tambang Batubara - Sebuah Pengalaman Observasi dan Penelitian Lapangan. Prosiding Seminar Hasil-Hasil Penelitian $11-23$. 